Article

\title{
In Transit: Sebald, Trauma, and Cinema
}

\author{
Allen Meek \\ School of English and Media Studies, Massey University, Palmerston North 4442, New Zealand; \\ A.Meek@massey.ac.nz
}

Received: 13 October 2017; Accepted: 14 December 2017; Published: 18 December 2017

\begin{abstract}
Because Sebald's books are preoccupied with historical catastrophe, particularly the Holocaust, critical commentaries have often interpreted them in terms of the transmission of traumatic memory. But this stress on the temporal relay from past to present and future generations has drawn attention away from the emphasis on space and travel in Sebald's work. In order to address this gap in Sebald criticism, this essay discusses three films that adapt and respond to Sebald's work: Patience (After Sebald) (directed by Grant Gee, 2012), Terezin (directed by Daniel Blaufuks, 2010) and Austerlitz (directed by Stan Neumann, 2015). Because of the cinema's constant movement between images and places, these films allow us to see more clearly the aspects of Sebald's writings concerned with traveling and making connections between different archival spaces. The journeys in Sebald's books and in these films inspired by them go beyond human life worlds to include non-human creatures, and beyond the realms of the living to include those inhabited by the dead. This suspension of the boundary between life and death, along with the restless movement from place to place, creates a relationship to memory and history that cannot be limited to the model of traumatic transmission.
\end{abstract}

Keywords: Sebald; trauma; postmemory; cinema; Holocaust

It does not seem to me, Austerlitz added, that we understand the laws governing the return of the past, but I feel more and more as if time did not exist at all, only various spaces interlocking according to the rules of a higher form of stereometry, between which the living and the dead can move back and forth as they like, and the longer I think about it the more it seems to me that we who are still alive are unreal in the eyes of the dead, that only occasionally, in certain lights and atmospheric conditions, do we appear in their field of vision (Sebald 2001, p. 185).

The passage cited above, from W.G. Sebald's Austerlitz, is spoken in the closing moments of Stan Neumann's film of the novel, suggesting that the director presents it as in some sense a conclusion not only of, but also about, the film. Could the various interlocking spaces referred to in this passage describe the different images and sequences that compose a cinematic montage? Does the cinema allow the living and the dead to move freely between different spaces? The cinema, wrote Walter Benjamin, opens up "a vast and unsuspected field of action" (Benjamin 2002, p. 117): it allows the juxtaposition of multiple spaces and the possibility of unlimited movement through those spaces. If we read this passage from Austerlitz as a description of cinema, then that movement extends from the worlds of the living to those of the dead. Benjamin goes on: "With the close-up, space expands; with slow motion, movement is extended" (Benjamin 2002, p. 117). Does film not also transport us to places where the dead, as well as the living, continue to make gestures and move about? This paradox is given a dramatic expression in Sebald's novel, in which the character Jacques Austerlitz has a slow-motion version made of a documentary so that he can search for an image of his mother, who died in Auschwitz.

The following discussion reconsiders some of Sebald's narratives and use of images in light of three films that adapt and respond to his work: Patience (After Sebald) (directed by Grant Gee (Gee 2012)), Terezin (directed by Daniel Blaufuks (Blaufuks 2010b) and Austerlitz (directed by Stan Neumann (Neumann 2015)). These cinematic versions of Sebald allow us to see more clearly the 
ways that his narratives are continually moving through different spaces inhabited by the living and the dead.

Influential writings on literature and cinema by Shoshana Felman, Cathy Caruth and Marianne Hirsch have focused on the transmission of traumatic memory through testimony. According to these theorists the overwhelming impact of violent and catastrophic events is registered in memory in the form of indelible traces that can be transmitted to others as an authentic experience of history. In this way trauma, although it may not be accessible to an individual's conscious understanding, can be recovered and become part of the collective memory of a particular group. In the writings of these critics historical trauma serves as the basis of identification with the sufferer, thereby bearing witness to a previously unacknowledged truth about the past. Traumatic experiences can be the cause of pathological conditions and behaviors and trauma theory invites us to enter "inside" this traumatized worldview. It is hardly surprising, then, that Sebald's work has invited critical commentary using trauma as an interpretive frame. Sebald's narratives about historical catastrophe feature characters that are disoriented and despairing as a result of surviving emigration, exile, war and genocide. These characters bear witness to a traumatic experience of history, their voices recorded in documentary style, accompanied by photographs of people, events, places and artifacts that appear to lend further authenticity to their testimony. The reader is invited to identify with these characters and experience their reality, with its melancholy heaviness, feelings of loss and sense of being lost.

The emphasis placed by these critics on identification, transmission, authenticity and truth, however, is less useful for understanding the intricate weaving of intertextual references and layering of genres in Sebald's books. Sebald's mixing of travelogue, history, testimony and archival materials suggests the genre of documentary, yet his texts also combine fact with fiction, authentic evidence with fake documents, narrative progression with obscure meditations and digressions. To interpret the elaborate construction of these texts as symptomatic of a pathological anxiety or obsession would be to willfully ignore their deliberate irony and ambiguity. This dimension of crafting is precisely what makes these texts "literary." The following discussion proposes that they are also usefully understood as "cinematic": Sebald's books recall the cinema in their restless movement between distant times and places, their juxtaposition of multiple spaces, and their suggestions of unexpected connections between disparate events and environments.

Rather than allowing us to experience historical trauma from the "inside," Sebald's multidirectional journeys and histories suggest a more permeable and porous boundary between past and present, life and death. The intrusive force of trauma cannot account for the diverse ways that memory is actively explored, carefully re-presented and intensively mediated in Sebald's work. His montage of image and text is not only full of parallel narratives and verbal echoes but includes forms of visual patterning that have influenced contemporary artists and filmmakers. There is a graphic dimension to Sebald's books that, along with the attention to architectural spaces and natural landscapes, makes the visual as important as the verbal. This mosaic construction does not easily lend itself to the notion of transmission of, or identification with, traumatic memory: instead it appears to continually defer and displace such identifications through spatial movement and visual correspondences.

Too often commentaries on Sebald explain his texts as embodying and communicating trauma at the expense of considering their complex spatial organization. For example, in her commentary on the passage from Austerlitz cited at the beginning of this essay, Luisa Banki writes: "What this image entails is the threatening dissolution of order into chaos ... identical with the danger of being overwhelmed by (actualised) traumatic memories" (Banki 2012, p. 43). Banki's commentary is consistent with psychoanalytic and psychotherapeutic accounts of trauma in which the individual subject is overwhelmed by specific memories of events so painful or incomprehensible at the time of their occurrence that they were not registered by the conscious mind. The memories of the events then return to the subject in later life in the form of nightmares, flashbacks, and pathological symptoms and behaviors. However, if we reconsider the particular passage that Banki cites from the novel, we see 
that the image is not one of chaos and dissolution but of "various spaces interlocking according to ... rules" (Sebald 2001, p. 185). What the character Jacques Austerlitz imagines is that these laws or rules that govern our relation to the past have to do with a spatial organization beyond our comprehension. Austerlitz "feels" this spatiality is not bound by the logic of linear temporality or to the distinction between life and death. Although this image of a "higher form of stereometry" (Sebald 2001, p. 185) is voiced by a character who can be understood as traumatized, this passage from the novel also suggests a self-reflexive commentary on the mixture of travelogue, history, testimony, and archival images in Sebald's fictions.

Continuing to read Sebald according to the logic of traumatic memory may be distracting us from better understanding the spatial organization of his narratives in which past and present, living and dead, co-exist in a non-temporal relationship. Trauma theory stresses the sudden and unexpected intrusion of the past into the present and the historical transmission of collective memory. In the Preface to her edited collection Trauma: Explorations in Memory, Caruth writes of the problem of "how to understand the nature of the suffering, without eliminating the force and truth of the reality that trauma survivors face and quite often try to transmit to us" (Caruth 1995a, p. vii). This emphasis on the particular truth of traumatic memory, along with its transmission from survivor to witness, links it to the collective identification with an authentic experience of history. In her Introduction, Caruth goes on to explain that this experience has a specific structure: "the event is not assimilated or experienced fully at the time, but only belatedly, in its repeated possession of the one who experiences it" (Caruth 1995b, p. 4). Caruth's theory of traumatic memory may at first appear to precisely describe the narrative about Jacques Austerlitz, who rediscovers his origins as a European Jew by recovering a memory of his arrival at Liverpool station as part of the Kindertransport that bought Jewish refugee children to England in World War II: his obsession with train stations can be explained in terms of this experience that he was not able to fully comprehend at the time of its occurrence. Yet Sebald's journeys do not only move between past and present but also make connections between multiple and diverse locations. In this way they divert us away from identification with a single historical truth or the experience of a particular group.

The proliferation of different spaces in Sebald's works and the often unexpected routes, passageways, and detours that connect them is foregrounded in the films about his works. This is particularly true of Patience (After Sebald), the subtitle of which is "A Walk through Rings of Saturn": the film re-enacts the walk through East Anglia described in Sebald's book but also "walks" the viewer through the book itself, using the guidance of experts on Sebald's work and associates of the author. The film uses digital mapping to show the dense complexity of connections between different places mentioned in the book. Movement between multiple locations also characterizes Neumann's film of Austerlitz, in which the director revisits the different places described in the novel and also talks about his own fascination with, and autobiographical connections to, the narrative. The idea of architecture and nature as archival spaces characterizes both Patience and the film version of Austerlitz. By repeating the journeys in Sebald's books, these films inquire into the ways that memory is embedded in human and natural environments. Sebald's writings themselves often use the strategy of following in the footsteps of others; for example, in his first book Vertigo he repeats a journey to Riva made earlier by Franz Kafka (Sebald 1999, pp. 141-67). Just as Sebald follows the trajectories of other writers, filmmakers have attempted to reproduce the journeys described in Sebald's books. Using the interpretive frames suggested by trauma theory, we might see these repetitions as symptomatic of a transmission of traumatic memory, even as a compulsive response to the historical traumas invoked in the novels. Howevert although walking and traveling can certainly be seen as compulsive activities, they also suggest active exploration, making choices based on impulse and curiosity, and a deliberate agency in terms of pursuing memory. Sebald's journeys not only allow encounters with the traumatic past, they also lead us to discover new configurations of memory and history and new constellations of disparate worlds. 


\section{Sebald and Shoah}

Restless traveling can be seen as a means of avoiding painful memories. Journeys can also deliberately return to places where calamities have occurred. Learning to recognize the legacies of the past in landscapes, cityscapes, and imagescapes demands a complex model of space and place that goes beyond the specific temporal structure of traumatic memory. Because Sebald's journeys are so persistently preoccupied with the legacies of historical catastrophe, and particularly of the Jewish Holocaust, Mark M. Anderson compares his works to Claude Lanzmann's famous documentary film Shoah, in which Lanzmann revisits the sites of the deportations and mass murder and interviews survivors and witnesses in the places where these atrocities occurred (Anderson 2003, pp. 106-7). In Lanzmann's film, as in Sebald's writings, cities, towns and landscapes suggest forms of memory and forgetting that exist alongside the individual testimony of the survivor witness.

As with Sebald's work, interpretations of Lanzmann's film have been dominated by the idea of traumatic transmission. This interpretive frame, however, has tended to neglect the various ways that the film traverses and dwells in different places. For example, Shoshana Felman writes that "Shoah is a film made exclusively of testimonies" (Felman and Laub 1992, p. 205). However, it is also a film about places and journeys; thus she comments: "Traveling between the living and the dead and moving to and fro between the different places and different voices in the film, the filmmaker is continuously—though discretely—present" (Felman and Laub 1992, p. 216). This sounds remarkably similar to Jacques Austerlitz's description of the spaces between which the living and the dead can move back and forth as they like, until Felman explains this movement more specifically in terms of an "inside" and "outside". Lanzmann, writes Felman, "takes us an a journey whose aim precisely is to cross the boundary, first from the outside world to the inside of the Holocaust, and back from the inside of the Holocaust to the outside world" (Felman and Laub 1992, p. 238). For Felman the point of Lanzmann's journey is to enter into the traumatic experience of the victim/survivor and to transmit this to the witness. The inside/outside polarity imposed on Lanzmann's journey to the sites of the Nazi genocide reinforces the identification with the victim that drives his film. In Sebald's writings, however, this identification is more indirect and more complexly mediated. His fictions and the films they have inspired suggest ways to think about memory, testimony, and archival images that transcend the model of traumatic transmission. In Sebald the boundaries between the insider's and outsider's experience are less important than the interconnections between different life worlds and scenes of death and decay.

The ways that movements through spaces and journeys to and from places are imagined is shaped by identifications with the groups that inhabit these spaces and places. Sebald, the non-Jewish German, creates the character Jacques Austerlitz who grows up in Wales unaware of his Jewish origins in Czechoslovakia. Whereas Sebald left his native Germany and pursued a career as an émigré academic in England, the assimilated French Jew Lanzmann went to Germany in 1947 to lecture on German philosophy at Berlin University. Lanzmann subsequently travelled to East Germany and to Israel, where he rediscovered his Jewish identity. For Felman, Lanzmann's journey in Shoah is about the struggle to bear witness from inside the Holocaust and through an identification with the Jewish victims and survivors (many of whom he finds in Israel). The witness, writes Felman, "embodies the return of the dead" (Felman and Laub 1992, p. 257). Trauma is always linked to the idea of recovery of what was lost or missing, and is then aligned with identification with a specific group. In Austerlitz's image of the living and the dead moving freely through various spaces, however, nothing is necessarily lost or recovered or transmitted. Instead there is a sense that the living and the dead co-exist, even if they do not always recognize each other. The living and the dead in Sebald's books never cohere into a single community. Rather they appear to encounter each other or pass each other by, like the inhabitants of some vast necropolis.

This sense of the co-existence of the living and the dead is memorably conveyed in Austerlitz in the title character's attempts to recover an image of his lost mother by repeatedly watching a slow-motion version of the Nazi documentary about Theresienstadt camp. Austerlitz can never be 
sure if he has found an image of his mother, as he has no conscious memory of her and has only a few old photographs upon which to base his idea of her appearance. This film, which shows a world inhabited by the dead, is also a false image of life in the camp fabricated by the Nazis and therefore cannot stand as an authentic record of past events. What it does incontestably show is a specific place, Theresienstadt, whose inhabitants have all been murdered.

\section{Sebald and Cinema}

Sebald's books, with their intensive use of photographs and other images and their descriptions of journeys and places, seem to invite the designation "cinematic." At various moments in Sebald's novels specific films are mentioned or discussed. ${ }^{1}$ In an essay on cinema in Sebald's work Mattias Frey compares Sebald's model of composition to cinematic montage, specifically as it is developed in the films of Alexander Kluge, Jean-Luc Godard and Alain Resnais (Frey 2007, pp. 231-2). Frey also develops a detailed analysis of a sequence of photographs in Austerlitz that record moving through the Theresienstadt camp (Frey 2007, pp. 233-36). This exploration of the camp as it stands today appears as an actual film sequence in Neumann's film of Austerlitz.

Austerlitz the novel includes visits to two now uninhabited Nazi camps: Breendonk in Belgium and Theresienstadt in Czechoslovakia. The image of returning to the ruins of the camps is used in both Resnais' Night and Fog and Lanzmann's Shoah. In Resnais' film the camera tracks across the deserted space of the camps, alternating with various archival photographs and documentary films from the period of the genocide. Lanzmann avoids archival images, but juxtaposes sequences shot in the now empty camps with the testimony of survivors and witnesses. Sebald's own montage of photographs taken at Theresienstadt doubtless makes a deliberate and self-conscious reference to these two iconic Holocaust documentaries. Film scholar Joshua Hirsch describes the opening sequence of Night and Fog, showing the barbed wire fences of Auschwitz, as situated at the border "between the present and the past, between the outside world and the inner world of the concentration camp" (Hirsch 2004, p. 48). Like Felman's reading of Shoah, he reads Resnais' film as transmitting traumatic memory. However, in Sebald's fictions any image, object, or place potentially becomes a threshold across which the narrator moves into another archival space. There is no inside or outside determined specifically by the experience or memory of the Holocaust.

Sebald's various references to films in his books, including those by Resnais and Kluge, and his use of photographs to document his journeys suggests that he at least partly intended an analogy between writer and filmmaker. This analogy both reinforces and exceeds the "traumatic" interpretation of Sebald's work. Photographs and film images preserve actual traces of people, things, places and events that are no longer present. In this way they suggest a strong analogy with the conception of traumatic memory as a literal trace of the past preserved outside conscious memory (Meek 2010, pp. 35-8). Indeed Amit Pinchevski has proposed that the audio-visual archive "might be considered the technological unconscious ... of what came to be known as 'trauma theory'" (Pinchevski 2011, p. 258), giving the example of the Fortunoff Video Archive for Holocaust Testimonies at Yale University, which became the basis for subsequent commentary and analysis by scholars such as Geoffrey Hartman, Dori Laub, and Lawrence Langer. Pinchevski argues that the location of specific moments when traumatic memories intrude into the survivor's testimony could only be analyzed because of "the ability to pause, rewind, and replay" (Pinchevski 2011, p. 259) videotape. The very notion that testimony could transmit a traumatic memory from survivor to witness was premised on the technological capabilities of recording, archiving, and replaying movement and sound.

1 See for example Vertigo (Sebald 1999, pp. 150-52), which describes Kafka's visit to the cinema; The Emigrants (Sebald 1996, p. 17), where a home move is compared to a sequence from Werner Herzog's Kaspar Hauser; The Rings of Saturn (Sebald 1998, p. 103), which describes a BBC documentary about Roger Casement; and Austerlitz, which includes references to Leni Riefenstahl's Triumph of the Will (p. 169) and Alain Resnais' documentary about the Bibliotheque Nationale, Tout le Mémoire du Monde (p. 261). 
Felman's and Hirsch's comparison of the journeys undertaken by Lanzmann and Resnais as moving from the outside to the inside of the Holocaust could also describe the process of recording, replaying and editing by which the filmmaker collects and shapes the materials. In this sense Sebald's character Austerlitz, an amateur photographer (like Sebald himself), becomes a filmmaker as he repeatedly watches and pauses the slow-motion version of the Nazi documentary of Thereienstadt. But if Shoah and the Fortunoff Video Archive allowed researchers to replay moments of testimony on order to recover moments of traumatic transmission, Sebald's approach to the audiovisual archive is quite different: when Austerlitz replays the slow-motion version of the Thereienstadt film, it is unclear whether anything is recovered or transmitted.

The notion of the transmission of trauma derives from psychological studies of second-generation experiences of the Holocaust: the trauma suffered by the parents was in some ways transmitted to the children, not by what was directly said but by what remained unsaid or was expressed in pathological behaviors (Hirsch 2004, p. 17). This transmission across generations is also relevant to larger claims about post-Holocaust Jewish identity. Again, however, Sebald's fictions do not easily conform to this account of traumatic transmission: first, the storyteller is a fabrication of the author and his statements are often composed of words borrowed from other texts; second, the process of identification is more indirect and complex because the Jewish character has no direct experience of the historical events of the Holocaust and his testimony is further mediated by the non-Jewish narrator. In Sebald's writings and their cinematic adaptations the movement between the worlds of the dead and the living does not always follow the logic of a collective identification. Rather, the present world of landscapes, buildings, artifacts, and images forms a potentially infinite series of archival spaces. The journey does not arrive at a final destination or a sense of belonging to a specific community of victims, survivors, or witnesses. The tension between archival images and living testimony that informs Lanzmann's intentions in Shoah does not apply to Sebald's works. All archival spaces, whether real places or documentary records, become sites of a possible encounter with an elusive past.

\subsection{Patience (After Sebald)}

A sense of an almost global meditation on historical catastrophe is conveyed in Grant Gee's film Patience (After Sebald), subtitled "A Walk through Rings of Saturn." The film is largely composed of interviews with a variety of interpreters and associates of Sebald and with artists who have been inspired by his work. The film superimposes these interviews and commentaries on images and passages of text from The Rings of Saturn, images of the places described in the journey around East Anglia described in the novel, and archival images and footage related to the various events and histories described in Sebald's text, including World War II bombing raids, silk worm farming, and fishing at Lowestoft. The film, then, carries the dense intertextuality of the book into an overtly hyper-textual film, where archival images and footage, verbal text, interviews, and films of actual places are continually juxtaposed and superimposed. To reinforce the sense that the film is a journey, there are shots from the point of view of the walker looking down on his legs and feet moving through the landscape, arms shown rowing a boat across glistening water, and atmospheric shots of places on the journey. The effect is that as we experience moving through the landscape we are also progressing through the text and images in the book. Marina Warner comments in the film that just as Sebald's "walks meander, his mind meanders and the pattern of the structure of the book meanders" (Gee 2012).

There is also an irony in this strategy, as interviewee Robert Macfarlane explains about his own attempt to reproduce the actual journey that forms the basis of the narrative in The Rings of Saturn: "It soon became obvious to me that the way to write about Sebald (I was wrong in this assumption) was to follow him, was to footstep in his foot-stepping of earlier feet and turn his own method back upon himself" (Gee 2012). Unfortunately this mimetic strategy produces unpredictable results: "I re-walked most of The Rings of Saturn walk and I really wanted it to be a grey day and it wasn't a grey day it was a bright day" (Gee 2012). Instead of immersing himself in Sebaldian melancholy, Macfarlane finds himself enjoying a refreshing swim in the sea. Should we take this anecdote as an ironic commentary 
on the folly of trying to recreate Sebald's book in Gee's film? The multitude of voices that offer commentary in Patience does contrast with the slow, meditative-almost hypnotic-effect of Sebald's prose. One senses Gee as a filmmaker trying to compensate for this somewhat chatty quality of the film with his use of faded black and white images, ambient piano music, and the deep voice (not Sebald's own but no doubt chosen to resemble his) that reads passages from the book.

Patience is composed of zooms on digital maps, grainy close-ups of printed texts, shots from moving trains and car windows tracking through landscapes and towns, the leisurely pace of the cutting mimicking the slow, meditative quality of Sebald's texts. The drama of historical events is never shown but felt as an absence, embodied in objects and places. In terms of cinema history, Patience returns to the style of the first Lumiere shorts, their still frames and long takes animated only by grass or leaves of trees moving gently in the wind, or the surface of waters shimmering with light. Sometimes a bird crosses the sky, a pedestrian crosses a street, or a car drives past the unmoving camera. In other places archival footage is modified through slow-motion effects, or there are slow zooms on still images. Images constantly merge into each other through dissolves and superimpositions. This slowness is only occasionally disrupted by a montage of rapid cuts used to convey psychological disorientation and distress. Just as Sebald's texts often resemble a report illustrated by dull black-and-white photographs, Patience uses all of the standard tropes of documentary-interviews, location shots, archival footage—and emphasizes their low-key production system and melancholy ambience. By attempting to reproduce the visual style of Sebald's texts, Patience reveals Sebald's profound debt to cinema as a visual language.

From the beginning of the film there is an emphasis on digital mapping in the work of artists such as Barbara Hui, who have tried to show the multiple links between the actual places included in Sebald's journey and all of the other places that are mentioned in the text. Indeed The Rings of Saturn superimposes a global history of catastrophe on the relatively small territory covered in Sebald's actual walk around East Anglia. Occasionally the film makes use of what looks like Google Earth. Sebald openly discusses his own resistance to computers and the idiocy of those who only research sitting in front of their screens. He stresses the necessity of taking actual journeys to real places in order to encounter true remnants, traces, and documents from the past. In its worst moments the film has a tendency to overload Sebald's solitary, reticent journeys with verbal commentary and technical effects, turning his meditations on time and place into something more akin to contemporary Internet-assisted tourism.

One of the more compelling insights in the film derives from Lise Patt's comparison of an image from the book showing piles of dead fish with another that appears a few pages later portraying victims of the Nazi death camps. This element of visual patterning leads her to comment: "He's become very, very important for contemporary artists, I think. And for that reason we have to reconsider and think of him as both a writer and an artist" (Gee 2012). This sense that Sebald may be an influential artist as well as writer resonates with the filmmaker's mission to turn Sebald's novel into an audiovisual text. For Patience is not just a documentary about Sebald's book, but a film that mimics, engages with, and extends both the narrative and visual dimensions of Sebald's work. Patience, then, brings out the visual-spatial dimensions of Sebald's text in ways that complicate the emphasis in Sebald commentary on trauma. For example, beyond the visual homology, how should we understand the comparison between dead fish in Lowestoft and dead humans at Belsen? There is certainly no moral equivalence being suggested between these two events, and yet Sebald does continually move back and forth between human catastrophe and the suffering of non-human creatures.

The connection between disparate events through pattern formation is further illuminated later in the film by artist Barbara Hui, who explains:

Sir Thomas Browne is a very important figure for Sebald in this book. Thomas Browne was a seventeenth century physician/theologian/philosopher/poet and talks about this Quincunx which is this pattern which consists of five nodes essentially and five lines between them, and the notion being that this pattern exists everywhere in nature, sort of 
like a primitive network. And it's sort of a very khabbalistic, premodern notion of seeing pattern in the world. And Sebald I think also in his writing is looking for these sorts of patterns, how they occur in historical events and connections between people. (Gee 2012)

Could Browne's Quincunx pattern be another name for the "higher form of stereometry" (Sebald 2001, p. 185) mentioned by Jacques Austerlitz? The patterning that allows us to make visual connections between the diverse images in Sebald's texts serves as a graphic language that traverses the usual boundaries between human and animal, past and present, life and death. This pattern formation thus recalls archaic ways of thinking, or mystical traditions such as the Kabbalah, while also corresponding to modern audiovisual languages such as cinematic montage and digital manipulations of the image.

Perhaps the most profound moment in the film comes in Adam Phillips's discussion of the melancholy temperament:

In this tradition of melancholy it's as though these people, people who feel this, are people who feel some inexplicable sense of loss. And they're people who try and locate this in history —as in, why am I feeling so fundamentally at a loss and so unattached? And it's as though the history gives you some sort of story about this but the feeling is somehow that there's been some catastrophe that can't be located and that one is living in the aftermath of that catastrophe. (Gee 2012)

This understanding of melancholy usefully relates Sebald's work to the notion of historical trauma at the same time as it differentiates it from Caruth's trauma theory or Marianne Hirsch's notion of postmemory, which tend to be exclusively preoccupied with specific events such as the bombing of Hiroshima or the Holocaust. Although the Holocaust features prominently in Sebald's writings, it is seldom isolated from other historical catastrophes. Marina Warner comments in the film on "his main preoccupation with how the genocidal wars of the twentieth century were foreshadowed by the Victorian Imperial wars" (Gee 2012). This statement is particularly true of The Rings of Saturn, which includes a long section on the Belgian genocide in the Congo, but these events resonate in sections of Austerlitz also. The narrator's first encounter with Austerlitz in the train station at Antwerp leads to an extended meditation on the bizarre architecture constructed in Belgium during the period of its colonial rule in Africa.

\subsection{Terezin}

The interconnections in Sebald's writings between various historical catastrophes are also prompted by the deliberate ambiguity that surrounds the images that appear in his texts. In a conversation with Christian Scholz, Sebald muses on his proclivity for finding images "enclosed in old books that one buys ... in antique shops or thrift shops." He comments further: "I've always noticed that an enormous appeal emanates from these images; a demand on the viewer to tell stories or to imagine what one could tell, by starting with these pictures" (Scholz 2007, p. 104). He goes on to link this attraction to archaic conceptions of life and death:

I believe that the black-and-white photograph, or rather the gray zones in the black-and-white photograph, stand for this territory that is located between death and life. In the archaic imagination it was usually the case that there was not only life and then death, as we assume today, but rather that in between there was this vast no-man's-land where people were permanently wandering around and where one did not know exactly how long one had to stay there ... (Scholz 2007, p. 108)

Sebald's novels re-present numerous photographs and other visual documents, including forgeries and fakes. It is the disjunction between the ambiguity that surrounds the image and the desire of the viewer to emotionally connect with it or to discover in it some previously undisclosed truth that 
creates the drifting, elusive effect of Sebald's narratives. Readers bring to his texts their own histories and memories and the desire to find in them a meaningful link with the past.

One such reader is Daniel Blaufuks, who made a short film inspired by images that are described in Austerlitz. Blaufuks is an artist who explores audiovisual media technologies and archives and their relation to personal and cultural memory. His works often address issues of travel, displacement, and statelessness and his research methods resonate strongly with Sebald's work. Blaufuks's Jewish German grandparents fled Nazi Germany to settle in Lisbon in 1936. In an interview he comments: "I like the idea of transmission, and that you give a different meaning to an unrelated snapshot someone did, perhaps with no further intentions. To change the status of the image that you find in the garbage, or flea market or, for that matter, in an archive" (Blaufuks 2012, p. 31).

Transmission, as a conveying of memory across space and time, also makes it possible to transform the significance of documents and to bestow new meanings on images. Although Blaufuks directly identifies himself with the victims of the Holocaust through his own family history, he also enlarges the idea of traumatic transmission to include Sebaldian aleatory effects. In his book Terezin Blaufuks (2010a) explains how in 1941 the Nazis began using Theresienstadt fortress in occupied Czechoslovakia as a ghetto for Jews who were to be deported to the death camps in the East. In 1942 the ghetto, which had been designed to house 7000 people, had over 50,000 inmates. Starvation and illness caused over 100 deaths a day. In preparation for a visit from the International Red Cross in 1944, the city was renovated and thousands of prisoners were transferred to other camps. A community center, children's nursery, post office, bank, gymnasium, library, theater, concert hall, synagogue, and coffee shop were established. The Red Cross workers were deceived by what they saw and, encouraged by the success of their deception, the SS decided to make a fake documentary film showing life in the camp. The film was completed in 1945 and shows the captive Jews enjoying concerts, sporting events, and other leisure activities, such as reading and walking in the sun. Kurt Gerron, the Jewish inmate who directed the film, was subsequently sent to Auschwitz. All those who were forced to appear in the film were also murdered in the death camps.

Blaufuks describes first encountering a photograph of the Theresienstadt camp-showing an office with a desk, files and a clock—reproduced in Sebald's novel Austerlitz. In 2001, the year in which Austerlitz was first published, Blaufuks also came into the possession of the diaries of an individual he calls Ernst K., covering his life as a young Jewish office worker in Berlin during the period from 1926 to 1930. After undertaking further research on Ernst K., Blaufuks discovered that he had been sent with his mother to the Theresienstadt camp in 1942. Blaufuks's interest in these diaries and the fate of Ernst K. recalls the materials and methods used by Sebald to compose his fictions: found objects, stray photographs without a full account of their original context, and research into the fate of missing or displaced persons, particularly those who suffered persecution or were murdered in the Holocaust. Blaufuks decided to repeat the experiment conducted by the fictional character in Sebald's novel: as noted at the beginning of this essay, Austerlitz has a slow-motion copy made of the Nazi Theresienstadt documentary and scrutinizes it hoping to glimpse his lost mother, who was sent from Theresienstadt to Auschwitz. Similarly, Blaufuks slows down the speed of the Nazi documentary to see whether he can find Ernst K. among the inmates. He does not say whether or not this search was successful.

Through the simplest of modifications of this film—slowing its speed and tinting it red-Blaufuks achieves an ominous, dream-like atmosphere. The inmates occupy a space bathed in red light and immersed in deep sound that recalls early experiments in electronic music. We see elderly people reading, playing cards, winding a ball of wool, attending lectures, listening to a concert, or sitting outdoors in the sun. Younger people are shown doing physical exercises, running a race, playing a game of soccer. Children are shown in hospital beds, eating bread, and singing in a concert. Craftsmen and artists, tailors and seamstresses, appear in their workshops and studios, while another man slowly hammers a nail. Blaufuks's film is not silent but, because the slow speed distorts the original soundtrack, it is non-verbal. The original voice-over commentary that relays false information about the camps is now disabled. In the novel the narrator describes this effect: 
At this point on that tape all that could be made out, Austerlitz continued, was a menacing growl such as I had heard only once before in my life, on an unseasonably hot May Day many years ago in the Jardin des Plantes in Paris when, after one of the peculiar turns that came over me in those days, I rested for a while on a park bench beside an aviary not far from the big cat's house, where the lions and tigers, invisible from my vantage point and, as it struck me at the time, said Austerlitz, driven out of their minds in captivity, raised their hollow roars of lament hour after hour without ceasing. (Sebald 2001, p. 250)

The official language of the Nazi bureaucracy, spoken in "high-pitched, strenuous tones" (p. 250) is revealed as a tormented, bestial howl expressing a kind of primal anxiety and terror. The violence behind the Nazi discourse of freedom through work is embodied in this deep, unsettling sound that could be aligned with the pre-verbal state of infancy. In a psychoanalytic sense, this would fit Sebald's fictional device of depicting Jacques Austerlitz searching in the film for his lost mother. The slow-motion version of the film enhances both its sinister intent and the terrible pathos of knowing that the inhabitants of the camp, going about their daily business, are all destined for destruction. It is as if the slow speed, rather than allowing the viewer to recover a lost memory, can only extend the moment before the inescapable arrival of catastrophe.

\section{Trauma and Postmemory}

Blaufuks's modification of the Theresienstadt film creates an immersive experience of this audiovisual archive. Despite Blaufuks's overt identification with the Holocaust victims who appear in this film, however, the question of traumatic transmission remains ambiguous. Blaufuks's use of Sebaldian strategies, including chance encounters and modification of archival materials, appears to suspend the distinction between life and death without any ultimate revelation of historical truth. This puts into question Marianne Hirsch's theory of postmemory, which has guided some interpretations of Sebald. ${ }^{2}$ In her essay "Surviving Images: Holocaust Photographs and the Work of Postmemory," Hirsch defines postmemory as "retrospective witnessing by adoption": "It is a question of adopting the traumatic memories—and thus also the memories—of others as experiences one might oneself have had; and of inscribing them into one's own life story" (Hirsch 2001, p. 10). In her book The Generation of Postmemory Hirsch argues that postmemory "approximates memory in its affective force and its psychic effects" (Hirsch 2012, p. 31) and is a specifically "generational structure of transmission embedded in multiple forms of mediation" (Hirsch 2012, p. 35). Hirsch's account of postmemory appears to usefully describe Blaufuks's Terezin and Neumann's film Austerlitz. In both cases the filmmakers are children of Jews who directly experienced the Holocaust. Their films attempt to, in Hirsch's words, "reactivate and re-embody" (Hirsch 2012, p. 33) the trauma and catastrophe experienced by their parents' generation.

Hirsch argues that Austerlitz "played an important role in enabling the work of postmemory of an entire generation" (Hirsch 2012, p. 40). The direct relation with Holocaust survivors, whose testimony is recorded in Shoah and in the Fortunoff Video Archive, is now less common and collective memory is becoming more dependent on archival documents. In this situation postmemory is "shaped more and more by affect, need, and desire and time and distance attenuate the links to authenticity" (Hirsch 2012, p. 48). Kathy Behrendt, however, argues that despite Hirsch's claims, Sebald's work does not fit her account of postmemory. When Austerlitz watches the Theresienstadt film, Behrendt emphasizes the way he is "overwhelmed by the details of the past" (Behrendt 2013, p. 59) that prohibits any clear identification with the victim or recovery of lost memory. She concludes that Sebald "is engaged in a different project, and one that is best not subsumed under the umbrella of postmemory work" (Behrendt 2013, p. 60). Behrendt does not elaborate further on what this project entails, other

2 See for example (Long 2003). 
than that it needs to be distinguished from postmemory, but the recent films that draw on Sebald's work may help us to clarify this distinction.

\section{Austerlitz}

In Stan Neumann's film of Austerlitz the voice of the novel's narrator is replaced by the commentary of the filmmaker. Unlike Sebald's German gentile narrator, Neumann is Jewish and his father was imprisoned in the Theresienstadt ghetto, suggesting a direct identification with Jacques Austerlitz. This identification also rests on Austerlitz as an amateur photographer and employs various optical devices to look at photographs. Austerlitz's request to view a slow-motion version of the Nazi documentary about Theresienstadt also characterizes him as a kind of filmmaker. At times this identification by the filmmaker with Austerlitz is stated directly. At one point the director's voice interjects: "The uneven cobblestones are firm beneath his feet, awaken his numbed senses and jolt his memory. Mine too. I see the same cobbles in photos of my childhood. And suddenly I see the book in an entirely new light, spawning the absurd idea that it was written just for me" (Neumann 2015).

The film is centered on the character of Austerlitz (played by Denis Lavant), who directly addresses the camera and delivers passages from the novel. Like Patience, the film is composed of journeys to different places featured in the novel-Antwerp, London (more specifically, Liverpool Street Station, the Great Eastern Hotel, and Greenwich), Paris (particularly the Bibliotheque Nationale, the Jardin des Plantes and the Gare d'Austerlitz), Marienbad, Trieste, Prague, Theresienstadt (but not Wales, the scene of Austerlitz's childhood)_and employs a Sebaldian aesthetic focusing on still photographs (some of them taken directly from the novel) but also including archival footage to give historical context, for example, the sequence that narrates the story of the German occupation of Czechoslovakia and portrays the progressive denial of civil rights to Jews.

The visual style of Neumann's Austerlitz shares much with Patience, although it is in color rather than black-and-white. The cinematography tends toward still frames and long takes, animated only by the wind in the trees or the slow movement of pedestrians through cityscapes. As in Patience, there are sequences shot from the windows of moving cars and trains. Black-and-white photographs feature prominently in close-up along with shots of the printed text of Sebald's book. As in Terezin, the Nazi documentary of the camp is reproduced in slow-motion, as described in Sebald's novel. Montages of still-framed images present various perspectives on buildings or landscapes. The melancholic pace and rhythms of Sebald's prose are translated into the cinematic languages of still images, slow cuts, slow motion and slow zoom.

The organizing metaphor in the film is architecture as a site of memory. The filmmaker uses architecture as a metaphor for trauma and identifies himself with this trauma: the destruction of the Jews in Europe. There are repeated images of boarded-up windows, suggesting that buildings contain secrets or traumatic memories that never see the light of day. The most poignant example of such an architectural secret in the book is the burial ground that lies beneath Liverpool Street Station and its connection with the Kindertransport that arrived there from Prague in 1939. This image reinforces the notion of traumatic transmission that underlies the filmmaker's obsession with the book-the sense that it holds a secret attraction that he must try to understand. The film closes with the filmmaker showing a photograph of his own father as a child in fancy dress, resembling the picture of Austerlitz as a child that appears on the cover of the book. In the filing room in the museum of the Theresienstadt ghetto the building takes on a specifically personal resonance for the filmmaker: "In March 1945 one of these cubbyholes contained my father's file: he was imprisoned here aged eighteen with his school resistance group. He alone survived. I was where the book had led me and has left me alone with the tenuous thread of my past" (Neumann 2015).

For Sebald, photography, film, architecture, and traumatic memory itself all appear as different forms of an encounter with something more archaic: the world of the dead. In the film of Austerlitz this return of the dead finds perhaps its strangest manifestation in the image of the stuffed squirrel seen in the window of a junk shop at Theresienstadt. This stuffed squirrel is mentioned but not 
shown in the novel. In the film it is linked to images of live squirrels in the park. Here the analogy suggested between animals and the spirits of the dead reminds us that Austerlitz begins in a zoo housing nocturnal animals-a nocturama: "It was some time before my eyes became used to its artificial dusk and I could make out different animals leading their sombrous lives behind the glass by the light of the pale moon" (Sebald 2001, p. 4). This description of the nocturama resonates with the later description of watching the slow-motion version of the Theresienstadt film:

The only animal which has remained lingering in my memory is the raccoon. I watched it for a long time as it sat beside a little stream with a serious expression on its face, washing the same piece of apple over and over again, as if it hoped that all this washing, which went far beyond any reasonable thoroughness, would help it to escape the unreal world in which it had arrived, so to speak, through no fault of its own. (Sebald 2001, p. 4)

The men and women employed in the workshops now looked as if they were toiling in their sleep, so long did it take them to draw needle and thread through the air as they stitched, so heavily did their eyelids sink, so slowly did their lips move as they looked wearily up at the camera. They seemed to be hovering rather than walking, as if their feet no longer quite touched the ground. The contours of their bodies were blurred and, particularly in the scenes shot out of doors, in broad daylight, had dissolved at the edges (Sebald 2001, p. 247).

\section{Conclusions}

Blaufuks and Neumann appear to conform to Hirsch's account of postmemory in their use of Sebald's narratives to allow a transgenerational transmission of trauma. They both explicitly carry Sebald's narrative in Austerlitz toward a direct identification with the Jewish victim. However, the journeys that organize Sebald's fictions carry over into those different films in ways that also suggest movement back and forth between the worlds of the living and the dead and a suspension of linear temporality. Sebald's journeys and archival excavations go beyond the relationship between generations to blur the boundaries between the living and the dead, the human and non-human, between creatures and their environments or life worlds. Sebald never begins from the point of view of a direct identification with the victim. Rather, his narratives of historical catastrophe usually begin with chance encounters, found images, and journeys without any specific purpose or destination. These encounters and journeys take place in various sites, all of which are imagined as archival spaces where life has been captured and recorded but is now missing its original context and has thereby become enigmatic and elusive but also an ever-present dimension of human experience. Despite Blaufuks's and Neumann's direct concern with generational transmission, their films cannot be fully understood in terms of postmemory. Sebald's narratives demand that we suspend identification with the trauma of the Jewish victims of the Holocaust, or even with the human victims of the endless series of catastrophes that compose world history. In these films based on Sebald's books we never remain for long in any single community: we are always in transit.

Conflicts of Interest: The author declares no conflict of interest.

\section{References}

Anderson, Mark M. 2003. The Edge of Darkness: On W.G. Sebald. October 106: 102-21. [CrossRef]

Banki, Luisa. 2012. Mourning, Melancholia and Morality: W.G. Sebald's German-Jewish Narratives. In Panic and Mourning: The Cultural Work of Trauma. Edited by Daniela Agostinho, Elisa Antz and Catia Fereira. Berlin: De Gruyter, pp. 37-48.

Behrendt, Kathy. 2013. Hirsch, Sebald, and the Uses and Limits of Postmemory. In The Memory Effect: The Remediation of Memory in Literature and Film. Edited by Russell J.A. Kilbourn and Eleanory. Ontario: Wilfred Laurier University Press, pp. 51-67.

Benjamin, Walter. 2002. Selected Writings, Volume 3, 1935-1938. Edited by Howard Eiland and Michael W. Jennings. Cambridge: Harvard University Press. 
Blaufuks, Daniel. 2010a. Terezin. Göttingen: Steidl.

Directed by Daniel Blaufuks. 2010b. Terezin.

Blaufuks, Daniel. 2012. Works on Memory: Selected Writings and Images. Cardiff: Fotogallery.

Caruth, Cathy. 1995a. Preface. In Trauma: Explorations in Memory. Edited by Cathy Caruth. Baltimore: Johns Hopkins University Press, pp. vii-ix.

Caruth, Cathy. 1995b. Introduction. In Trauma: Explorations in Memory. Edited by Cathy Caruth. Baltimore: Johns Hopkins University Press, pp. 3-12.

Felman, Shoshana, and Dori Laub. 1992. Testimony: Crises of Witnessing in Literature, Psychoanalysis, and History. New York and London: Routledge.

Frey, Mattias. 2007. Theorizing Cinema in Sebald and Sebald with Cinema. In Searching for Sebald: Photography after W.G. Sebald. Edited by Lise Patt. Los Angeles: Institute of Cultural Inquiry, pp. 226-41.

Directed by Grant Gee. 2012, Patience (After Sebald). Santa Monica: Illuminations Films.

Hirsch, Marianne. 2001. Surviving Images: Holocaust Photographs and the Work of Postmemory. Yale Journal of Criticism 14: 5-37. [CrossRef]

Hirsch, Joshua. 2004. Afterimage: Film, Trauma, and the Holocaust. Philadelphia: Temple University Press.

Hirsch, Marianne. 2012. The Generation of Postmemory: Writing and Visual Culture after the Holocaust. New York: Columbia University Press.

Long, J. J. 2003. History, Narrative, and Photography in W.G. Sebald's Die Ausgewanderten. Modern Language Review 8: 117-37. [CrossRef]

Meek, Allen. 2010. Trauma and Media: Theories, Histories and Images. New York and London: Routledge.

Directed by Stan Neumann. 2015, Austerlitz. Strasbourg: ARTE France, Paris: Les Films d'IcI.

Pinchevski, Amit. 2011. Archive, Media, Trauma. In On Media Memory: Collective Memory in a New Media Age. Edited by Motti Neiger, Oren Meyers and Eyal Zandberg. New York: Palgrave MacMillan, pp. 253-64.

Scholz, Christian. 2007. 'But the Written Word is Not a True Document': A Conversation with W.G. Sebald on Literature and Philosophy. In Searching for Sebald: Photography after W.G. Sebald. Edited by Lise Patt. Los Angeles: Institute of Cultural Inquiry, pp. 104-9.

Sebald, W. G. 1996. The Emigrants. Translated by Michael Hulse. New York: New Directions.

Sebald, W. G. 1998. Rings of Saturn. Translated by Michael Hulse. New York: New Directions.

Sebald, W. G. 1999. Vertigo. Translated by Michael Hulse. New York: New Directions.

Sebald, W. G. 2001. Austerlitz. Translated by Anthea Bell. New York: Random House.

(C) 2017 by the author. Licensee MDPI, Basel, Switzerland. This article is an open access article distributed under the terms and conditions of the Creative Commons Attribution (CC BY) license (http:/ / creativecommons.org/licenses/by/4.0/). 